\title{
Values of rainfall erosivity factor for the Czech Republic
}

\author{
Miloslav Janeček $^{1}{ }^{*}$, Vít Květoň ${ }^{2}$, Eliška Kubátová ${ }^{1}$, Dominika Kobzová ${ }^{1}$, \\ Michaela Vošmerová ${ }^{1}$, Jana Chlupsová ${ }^{1}$ \\ ${ }^{1}$ Czech University of Life Sciences Prague, Faculty of Environmental Sciences, Department of Land Use and Improvement, Kamýcká 129 , \\ 16521 Prague 6, Czech Republic. \\ ${ }^{2}$ Czech Hydrometeorological Institute Prague, Žabovřeská 250, 15627 Prague 5-Zbraslav, Czech Republic. \\ ${ }^{*}$ Corresponding author. Tel: +420 224382 128. E-mail: janecekm@fzp.czu.cz
}

\begin{abstract}
The processing of ombrographic data from 29 meteorological stations of the Czech Hydrometeorological Institute (CHMI), according to the terms of the Universal Soil Loss Equation for calculating long term loss of soil through water erosion, erosion hazard rains and their occurrence have been selected, with their relative amount and erosiveness $R$-Factors determined for each month and years. By comparing the value of the time division of the $R$-Factor in the area of the Czech Republic and in selected areas of the USA it has been demonstrated that this division may be applied in the conditions of the Czech Republic. For the Czech Republic it is recommended to use the average value $R=40$ based on the original evaluation.
\end{abstract}

Keywords: Water erosion; Rainfall-erosivity factor; Rainfall.

\section{INTRODUCTION}

For many years the so-called Universal Soil Loss Equation (USLE) for calculating long-term loss of soil due to erosion, according to Wischmeier and Smith $(1965,1978)$, has been widely used in the Czech Republic for determining soil erosion risks and evaluating the effectiveness of anti-erosion measures. The form of the above-mentioned equation is:

$G=R \times K \times L \times S \times C \times P$,

where $G$ is mean annual soil loss $\left(\mathrm{t} \mathrm{ha}^{-1}\right.$ year $\left.^{-1}\right), R$ is rainfall erosivity factor, $K$ is soil erosivity factor, $L$ is slope length factor, $S$ is slope steepness factor, $C$ is crop management factor, $P$ is erosion control practice factor.

The rainfall factor $R$, i.e. its erosivity, has been formulated in the USA (Wischmeier and Smith, 1965). The aforementioned had the largest amount of necessary data accessible at that time, acquired from a network of meteorological survey stations situated throughout the USA. The rainfall factor used for determining the average annual loss of soil includes the influence of exceptional precipitation events (intensive rainfall) as well as average intensive rains.

The data indicate that, when factors other than rainfall are held constant, soil losses in an area are directly proportional to a rainstorm parameter: total energy of the rain $(E)$ times the maximum 30-min intensity $\left(i_{30}\right)$ :

$R=E \cdot i_{30} / 100$

where $R$ is rainfall erosivity factor $\left(\mathrm{MJ} \mathrm{ha}^{-1} \mathrm{~cm} \mathrm{~h}^{-1}\right), E$ is total energy of the rain $\left(\mathrm{J} \mathrm{m}^{-2}\right), i_{30}$ is maximum 30 -min intensity $(\mathrm{cm}$ $\mathrm{h}^{-1}$ ).

The total energy of the rain is:

$$
E=\sum_{i=1}^{n} E_{i},
$$

where $E_{i}$ is the kinetic energy of rain in the $i$-section ( $n$ - number of rain sections):
$E_{i}=\left(206+87 \log i_{s i}\right) \cdot H_{s i}$,

where $i_{s i}$ is the intensity of rain in the $i$-section $\left(\mathrm{cm} \mathrm{h}^{-1}\right), H_{s i}$ is rain total in the $i$-section $(\mathrm{cm})$.

The occurrence of deep rill erosion and large amounts of sediment deposits after extreme or intense precipitation has led to the conclusion that important erosion events occur in connection with torrential precipitations and according to maximum intensity. However, according to Wischmeier and Smith (1965), data collected at several locations in the USA have shown that this is not the case.

The data have shown that the $R$-Factor used for average yearly soil loss must include the cumulative impact of exceptional precipitation events (torrential rains) as well as the impact of precipitation with an average intensity. The average yearly value of the $R$-Factor is determined on the basis of longterm precipitation observations and represents the sum of the yearly erosive impact of each torrential precipitation $\left(i_{30}\right)$, i.e. precipitations with a total of at least 0.5 inch $(12.5 \mathrm{~mm})$, provided that at least 0.25 inch $(6.25 \mathrm{~mm})$ have fallen within 15 $\min$.

Rains which occur more than 6 hours after other precipitation events are considered separately. According to Wischmeier and Smith (1965) the $R$-Factor for a specific locality represents the long-term average yearly sum of the kinetic energy coefficient $\left(E_{i}\right)$ of each torrential rain and its highest 30-min intensity $\left(i_{30}\right)$.

In the USA the Rainfall erosivity and runoff factor, i.e. erosive impact of rain $-R$, has been assessed for each region in the form of isoerodentic lines which have been charted on a US map and published in Agriculture Handbook No. 282 (Wischmeier and Smith, 1965) and Agriculture Handbook No. 537. Wischmeier and Smith (1978) indicate that the coefficient of conversion from U.S. units to S.I. units is 1.735 . Therefore, the rainfall erosivity factor $R$ depends on the frequency of occurrence, kinetic energy, intensity and rain fall.

Similarly, this factor was regionalized in some other countries: in Germany, an $R$-Factor was calculated for the Bavaria region by Schwertmann et al. (1987) according to the procedure according Wischmeier and Smith (1978). It was found that the values of $R$-Factor significantly correlated with average annual 
rainfall of $N(\mathrm{~mm})$ and even better, with average summer rainfall $N S(\mathrm{~mm})$ and varies between $40-140 \mathrm{MJ} \mathrm{ha}^{-1} \mathrm{~cm} \mathrm{~h}^{-1}$. For the whole of Germany, $R$-Factor values were determined by Deumlich (1993) and further correlation was achieved with average annual precipitation totals during the summer (MaySeptember). According to Auerswald et al. (2009) the average $R$-Factor for the rural area is approximately equal to Germany's $58 \mathrm{MJ} \mathrm{ha}^{-1} \mathrm{~cm} \mathrm{~h}^{-1}$. Additionally, several studies dealing with the determination of the $R$-Factor have been conducted in Austria (Klik and Baumer, 1996). The current value for the $R$ Factor in the Slovak Republic is equal to $20 \mathrm{MJ} \mathrm{ha}^{-1} \mathrm{~cm} \mathrm{~h}^{-1}$, however, Fulajtár (2003) is working to refine this value as it should be substantially higher. In Hungary the calculation of $R$ Factor was also formulated (Wischmeier and Smith, 1978) and average values were found to be from 40 to $50 \mathrm{MJ} \mathrm{ha}^{-1} \mathrm{~cm} \mathrm{~h}^{-1}$ (Roksandic, 2011). For Poland, the same average $R$-Factor of 60.6 $\mathrm{MJ} \mathrm{ha}^{-1} \mathrm{~cm} \mathrm{~h}^{-1}$ was determined by Rejman et al. (1998) as well as by Wischmeier and Smith (1978). In Belgium, Salles et al. $(2002,1999)$ found an average annual $R$-Factor value of 87.1 $\mathrm{MJ} \mathrm{ha}^{-1} \mathrm{~cm} \mathrm{~h}^{-1}$, continued in the calculations Verstraeten et al. (2006). In Finland, the average $R$-Factor for a given study area was determined by Wordof (2011) as $30.3 \mathrm{MJ} \mathrm{ha}^{-1} \mathrm{~cm} \mathrm{~h}^{-1}$.
For France, the $R$-Factor has been investigated by Strauss et al. (1997), and for Italy, Diodato (2004) and Diodato and Bellocchi (2009) determine the values of $R$-Factor to be $200 \mathrm{MJ} \mathrm{ha}^{-1}$ $\mathrm{cm} \mathrm{h}^{-1}$. In Slovenia, the value rainfall erosivity index $E_{i 30}$ was determined in the range of $1580-2700 \mathrm{~mm} \mathrm{ha}^{-1} \mathrm{~h}^{-1} \mathrm{yr}^{-1}$ by Petrovšek and Mikoš (2004) and Braunovič et al. (2009). For non-European countries, $R$-Factors have been reported for Japan by Santos et al. (2010), for parts of Africa by Angima et al. (2002) and recently, Bonilla and Vidal (2011) observed very considerable differences in the $R$-Factor for different regions of Chile from 7.1 to $402.5 \mathrm{MJ} \mathrm{ha}^{-1} \mathrm{~cm} \mathrm{~h}^{-1}$. It would be possible to list other countries, but in principle it can be stated that the vast majority of procedures are based on relationships reported by Wischmeier and Smith (1978).

\section{METHODS AND MATERIALS}

During the calculation of the $R$-Factor for the region of the Czech Republic, the method of Wischmeier and Smith (1978) has been systematically implemented. Preference has been given to survey stations producing long term ombrographic observation data (Table 1 and Fig. 1).

Table 1. $R$-Factor values assessed from data measured at ombrographic stations of the CHMU in MJ ha ${ }^{-1} \mathrm{~cm} \mathrm{~h}^{-1}$.

\begin{tabular}{|c|c|c|c|c|c|c|c|c|c|}
\hline \multirow{2}{*}{ Measuring station } & \multirow{2}{*}{ Observation period } & \multirow{2}{*}{$\begin{array}{c}\text { Number of } \\
\text { years }\end{array}$} & \multicolumn{4}{|c|}{ Number of erosive rains } & \multirow{2}{*}{$\begin{array}{l}\text { Total } \\
\text { of all } R\end{array}$} & \multirow{2}{*}{$\begin{array}{c}\varnothing R \text { from } \\
\text { years (all } \\
\text { rains) }\end{array}$} & \multirow{2}{*}{$\begin{array}{c}\varnothing R \\
\text { from } \\
\text { erosive } \\
\text { rains }\end{array}$} \\
\hline & & & all cases & $\varnothing$ per year & $\min$ & $\max$ & & & \\
\hline 1 & 2 & 3 & 4 & 5 & 6 & 7 & 8 & 9 & 10 \\
\hline Brumov Bylnice & $1961-1990$ & 29 & 82 & 2.8 & 0 & 7 & 1713.2 & 59.1 & 20.9 \\
\hline Červená & $1961-2000$ & 40 & 100 & 2.5 & 0 & 10 & 1763.7 & 44.1 & 17.6 \\
\hline Desná & $1961-2000$ & 38 & 97 & 2.6 & 0 & 7 & 1686.7 & 44.4 & 17.4 \\
\hline Deštné & $1981-2000$ & 19 & 61 & 3.2 & 0 & 7 & 1423.5 & 74.9 & 23.3 \\
\hline Doksany & $1952-2000$ & 48 & 78 & 1.6 & 0 & 5 & 1509.3 & 31.4 & 19.3 \\
\hline Doksy & $1962-2000$ & 39 & 88 & 2.3 & 0 & 6 & 1602.5 & 41.1 & 18.2 \\
\hline Hejnice & $1970-2000$ & 31 & 82 & 2.6 & 0 & 6 & 1671.1 & 53.9 & 20.4 \\
\hline Horní Bečva & $1962-2000$ & 39 & 113 & 2.9 & 1 & 12 & 2622.4 & 67.2 & 23.2 \\
\hline Hradec Králové & 1961-1994 & 33 & 72 & 2.2 & 0 & 7 & 1940.8 & 58.8 & 27.0 \\
\hline Cheb & $1960-2000$ & 41 & 69 & 1.7 & 0 & 6 & 1239.9 & 30.2 & 18.0 \\
\hline Churáňov & $1955-2000$ & 46 & 108 & 2.3 & 0 & 6 & 2376.7 & 51.7 & 22.0 \\
\hline Kostelní, Myslová & 1961-2000 & 40 & 87 & 2.2 & 0 & 7 & 1919.7 & 48.0 & 22.1 \\
\hline Liberec & $1961-87,1991-2000$ & 36 & 67 & 1.9 & 0 & 4 & 1633.6 & 45.4 & 24.4 \\
\hline Neumětely & $1981-2000$ & 20 & 39 & 2.0 & 0 & 5 & 505.0 & 25.3 & 12.9 \\
\hline Pohořelice & $1963-2000$ & 37 & 81 & 2.2 & 0 & 5 & 1509.0 & 40.8 & 18.6 \\
\hline Praha-Libuš & $1972-2000$ & 29 & 69 & 2.4 & 0 & 6 & 1228.4 & 42.4 & 17.8 \\
\hline Přibyslav & $1965-2000$ & 36 & 89 & 2.5 & 0 & 7 & 1723.9 & 47.9 & 19.4 \\
\hline Přimda & $1957-2000$ & 43 & 71 & 1.7 & 0 & 5 & 1091.9 & 25.4 & 15.4 \\
\hline Raškovice & $1962-68,70-85,97-2000$ & 27 & 99 & 3.7 & 1 & 9 & 1855.7 & 68.7 & 18.7 \\
\hline Rýmařov & 1963-2000 (the failure & 28 & 79 & 2.8 & 0 & 5 & 1559.1 & 55.7 & 19.7 \\
\hline Svratouch & 1956-2000 & 44 & 103 & 2.3 & 0 & 9 & 2184.1 & 49.6 & 21.2 \\
\hline Tábor & $1961-1996$ & 36 & 80 & 2.2 & 1 & 5 & 1450.7 & 40.3 & 18.1 \\
\hline Třeboň & $1923-41,44-80,82-2000$ & 74 & 195 & 2.6 & 0 & 6 & 4200.5 & 56.8 & 21.5 \\
\hline Ústí n.Orlicí & $1981-2000$ & 20 & 48 & 2.4 & 0 & 6 & 1006.4 & 50.3 & 21,0 \\
\hline Varnsdorf & $1963-2000$ & 37 & 75 & 2.0 & 0 & 6 & 1221.5 & 33.0 & 16.3 \\
\hline Velké Meziříčí & 1961-1999 & 39 & 79 & 2.0 & 0 & 6 & 1888.6 & 48.4 & 23.9 \\
\hline Vír & $1961-2000$ & 40 & 99 & 2.5 & 1 & 9 & 2049.0 & 51.2 & 20.7 \\
\hline Vizovice & $1962-1998$ & 37 & 113 & 3.1 & 0 & 8 & 2186.4 & 59.1 & 19.3 \\
\hline Vranov & $1962-2000$ & 39 & 90 & 2.3 & 0 & 5 & 1754.4 & 45.0 & 19.5 \\
\hline Zbiroh & $1963-2000$ & 36 & 76 & 2.1 & 0 & 6 & 1682.3 & 46.7 & 22.1 \\
\hline Židlochovice & $1962-2000$ & 38 & 76 & 2.0 & 0 & 5 & 1552.9 & 40.9 & 20.4 \\
\hline Average & & 36.7 & 86.0 & 2.4 & & & 1734.0 & 47.7 & 20.0 \\
\hline
\end{tabular}




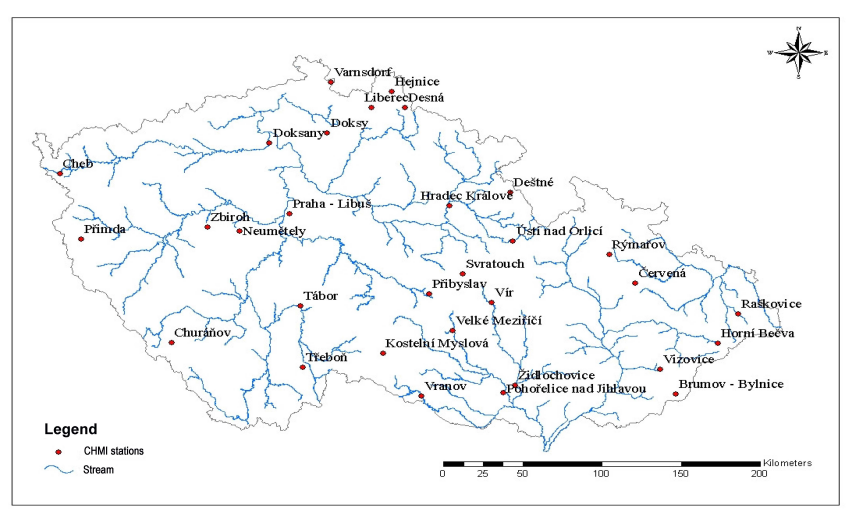

Fig. 1. Locations of CHMI ombrographic survey stations used for calculation of R-Factors.

Data records have been fed into a text editor in digital form with a time interval of 1 minute. Prior to this, the calculated data was screened to remove precipitations which did not comply with the above mentioned criteria.

Through systematic assessment of precipitation data collected from 31 CHMI ombrographic stations in the Czech Republic, the $R$-Factor values are determined, as shown in Table 1 .

In Table $1, R$-Factor values are listed where assessed precipitations fulfilled the aggregate criterion of higher than 12.5 $\mathrm{mm}$ with intensity $\geq 6.25$ in a period of $15 \mathrm{~min}$ (erosive rains). $R$-Factor values are indicated as the sum for the entire observed period (Col. 8), average annual sum (Col. 9). The average annual sum of $R$-Factor for the Czech Republic was set at $R=48$ $\mathrm{MJ} \mathrm{ha} \mathrm{cm} \mathrm{h}^{-1}$ which is the average value for one rain (data from 31 ombrographic stations in the Czech Republic). However, used stations are not spatially distributed equally in the Czech Republic and the number of observed years at each of the stations is not the same (Pavelkova et al., 2012). Therefore, the regionalisation of the $R$-Factor values for the entire area of the Czech Republic was not conclusive. For this reason, the authors have decided to use $R$-Factor estimations based on full time series of daily precipitation totals of 257 of the rain gauge stations of the CHMI from the observation period 1971-2000, i.e. 30 years.

A number of regression analyses were performed to find the best estimation of the annual sum of $R$-Factor using daily precipitation totals. Analyses were based on a comparison between ombrographic data (Table 1 except stations Červená and Churáňov which were not usable in time of analyses) and coincident daily rain gauge data. The "Training set" comprised 2441 days with an occurrence of erosive rains according to the ombrograph. The best estimation of the annual sum of $R$-Factor was counted as follows:

Ester $11=$ Ester $*$ Ratio,

where value "Ester" is yearly sum of $R$-Factors calculated according to Eq. (1) assuming even spreading during a day for days with daily precipitation totals $\geq 12.5 \mathrm{~mm}$. The regression dependence of "Ratio" is "Annual count of days with erosive rains (see col. (5) Table 1)/(annual number of days in which Ester $>0)$ “. The regression equation

Ratio $=(0.36577-0.00020 *$ altitude $(\mathrm{m}$ a.s.1. $))$

was used $(R$-square $=0.031$, sign. 0.000$)$.
Table 2. Distribution of the $R$-Factor values (MJ $\mathrm{ha}^{-1} \mathrm{~cm} \mathrm{~h}^{-1}$ ) according to altitudes in the region of Idaho (USA).

\begin{tabular}{lcccc}
\hline \multirow{2}{*}{$\begin{array}{l}\text { Altitude } \\
\text { (m a.s.1.) }\end{array}$} & \multicolumn{4}{c}{$R$-Factor value } \\
\cline { 2 - 5 } & \multicolumn{2}{c}{ Wischmeier (1973) } & Renard et al.(1997) \\
\cline { 2 - 5 } & vegetative & year & vegetative & year \\
\hline 1184 & 21.45 & 24.34 & 26.55 & 28.93 \\
1649 & 24.34 & 30.13 & 28.93 & 34.04 \\
1454 & 27.23 & 36.93 & 31.49 & 39.49 \\
1649 & 30.13 & 52.59 & 34.04 & 51.23 \\
2073 & 30.13 & 71.14 & 34.04 & 64.17 \\
2164 & 36.93 & 92.93 & 39.49 & 77.95 \\
\hline
\end{tabular}

Quality of estimation was verified by a paired $t$-test of annual $R$-Factor totals computed on the one hand from minute ombrographic data by Eq. (1) and on the other hand from daily rain gauge data by Eq. (2) (1064 pairs of annual values). It was performed with the following results: average difference 0.19 $\mathrm{MJ} \mathrm{ha}^{-1} \mathrm{~cm} \mathrm{~h}^{-1}$, std. dev. 48.73, std. error $1.49, T$-value 0.12 , signif. 0.901 (i.e. no significant difference). Afterwards, estimation of Ester 11 was computed for each from the above mentioned 257 time series. Finally, spatial analysis in GIS environment was performed (taking into account linear altitude dependence of Ester 11) using digital geography of the Czech Republic (resolution $1 \mathrm{~km}$ ).

To justify this step, the authors refer to Wischmeier and Smith (1978) and Renard (1997), who have indicated the following distribution of the $R$-Factor values at various altitudes in the region of Idaho (USA) - see Table 2.

\section{RESULTS AND DISCUSSION}

The station's yearly sum of $R$-Factor calculated from ombrographic data oscillated between 0 and 415 , with an average for the analysed years of $47.7 \mathrm{MJ} \mathrm{ha}^{-1} \mathrm{~cm} \mathrm{~h}^{-1}$ and standard deviation $48.8 \mathrm{MJ} \mathrm{ha}^{-1} \mathrm{~cm} \mathrm{~h}^{-1}$. The variability between the stations was quite strong, the station's averages of yearly $R$ Factors sums during the period of observation of each station lied between 25.3 and $74.9 \mathrm{MJ} \mathrm{ha}^{-1} \mathrm{~cm} \mathrm{~h}^{-1}$, depending on the observed year and the station (Table 1, Col. 9).

The spatial average $R$-Factor over the Czech Republic was calculated from 257 stations based on index Ester 11 for each year of the period 1971-2000. This is depicted on Fig. 2. Only days with liquid precipitations was applied. Extreme values of $R$-Factor occurred sporadically.

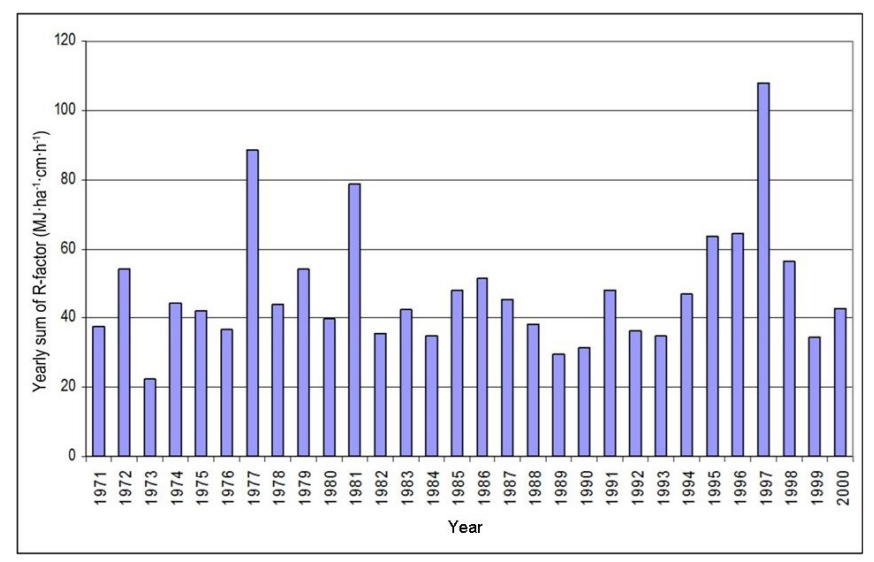

Fig. 2. The progression of yearly sum of $R$-factor $\left(\mathrm{MJ} \mathrm{ha}^{-1} \mathrm{~cm} \mathrm{~h}^{-1}\right)$ during the period $1971-2000$. 
Results of spatial analysis in GIS environment of the arithmetic average of the annual sums of $R$-Factors for the period $1971-2000$ (Fig. 3) and a map of the trimmed arithmetic average of the $R$-Factors (average for 26 years, without two smallest and two largest annual value on each station) (Fig. 4) were charted. (Note, the maps are based on the yearly sum of $R$ Factor estimated by index Ester 11, which was calculated from 257 full time series of precipitation data (i.e. without gaps). There are two reasons for using the trimmed average. First, the average spatial distribution of the yearly sum of $R$-Factor is substantially affected by rare local extreme rains. Secondly, the potential influence of estimation excess is suppressed. A comparison of various methods for calculating the mean value is shown in Table 3.

Table 3. Comparison of various methods for calculating the mean value of station estimates of the $R$-Factor for the period 1971-2000 $\left(\mathrm{MJ} \mathrm{ha}^{-1} \mathrm{~cm} \mathrm{~h}^{-1}\right)$ for 257 stations $(30$ years $=$ all years, 26 years $=$ minus the lowest and the highest values, 24 years $=$ minus three lowest and three highest values; median = average 15 and 16 values of each station when sorted according to size.

\begin{tabular}{lccrc}
\hline \multirow{2}{*}{ Statistics } & \multicolumn{3}{c}{ Arithmetic average } & \multirow{2}{*}{ Median } \\
\cline { 2 - 4 } & 30 years & 26 years & 24 years & \\
\hline Average & 47.8 & 43.7 & 42.9 & 40.0 \\
Standard deviation & 21.9 & 18.0 & 17.5 & 15.9 \\
Minimum & 18.4 & 17.7 & 17.6 & 15.3 \\
Maximum & 145.0 & 116.0 & 112.1 & 100.7 \\
\hline
\end{tabular}

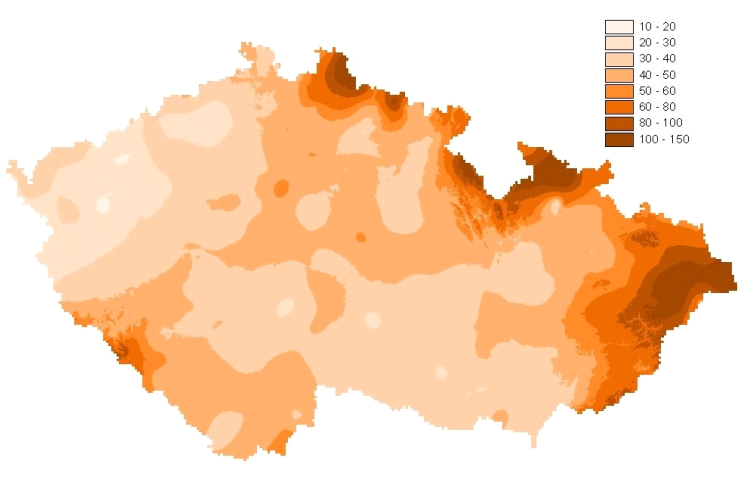

Fig. 3. Area distribution of the average yearly sum of $R$-Factors the in Czech Republic 1971-2001.

The applied $R$-Factor calculation for the Czech Republic is very sophisticated when we have minute dates. Currently, this calculation is based on the processing of minute ombrograph values, which have been measured and digitalized by the CHMI. We particularly focused on analysis and estimation of the $R$-Factor year aggregate. In the given case it is possible to consider the $R$-Factor as an analogy of the cumulated temperatures above a designated limit.

While searching for the area spatial distribution of the $R$ Factor, we encountered many problems related to the insufficiently dense network of the assessed $R$-Factors from minute values and with an inconsistent observation period. In the set of assessed $R$-Factors many questions remain. Besides the problem of unassessable ombrograph data, there is the problem of categorisation; which rains should be included in the calculations of the $R$-Factors?

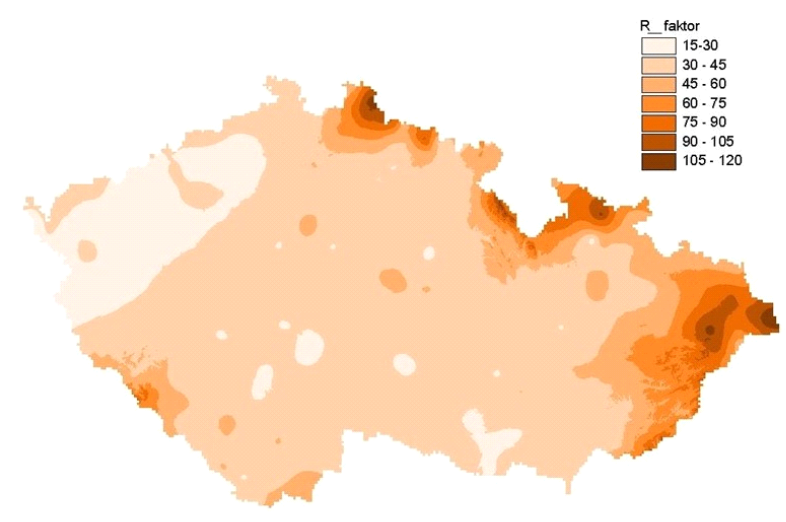

Fig. 4. Area distribution of the truncated mean estimate (minus 2 smallest and 2 biggest yearly sums for each station) of $R$-Factors in the Czech Republic 1971-2001.

It is not possible to set a consistent yearly interval proposed for the measurement of the snow blanket, because this depends on the geographic location of the station (in the conditions of the Czech Republic, mainly on its altitude), and on the specific weather in any given year.

During warm years this period will be longer, during cold years shorter. At higher altitudes it will be shorter than at lower altitudes. During the elaboration of the map, the assessed days of a year were defined on the condition that they must be days with rain, not with snow. At some stations, there are instruments with a heated rain gauge. Such data, of course, do not provide information on the type of precipitation. The influence of the height of the snow blanket on the days included in the calculation must also be considered. It may be assumed that in the relation between liquid precipitation and the total mass of the snow blanket, infiltration of rain water is allowed without erosive impact. These must be evaluated separately within the process of snow melting. As far as the extent of the work goes, it was only possible to formulate a basic estimate of the extent of possible impact. In the future, the problem of the time sequences of erosive rains must be addressed. Also, the problem of the influence of soil saturation on the accuracy of the calculation methods of each $R$-Factor should be addressed.

While evaluating the mean erosion impact in each region of the Czech Republic, it should be considered that the station average in a given period may include exceptional rains, e.g. Usti nad Orlicí in 1988 and floods in Moravia in 1997, which have a very small periodicity of occurrence. This problem has been solved within the framework of the project by means of a truncated mean which omits the two smallest and two greatest yearly values at each station. The area truncated mean of the year by estimating the sum of the $R$-Factor in the Czech Republic in the period 1971-2000 amounts to $41.1 \mathrm{MJ} \mathrm{ha}^{-1} \mathrm{~cm} \mathrm{~h}^{-1}$, with area variations from 17.8 to $112.7 \mathrm{MJ} \mathrm{ha}^{-1} \mathrm{~cm} \mathrm{~h}^{-1}$.

The highest values were assessed in mountainous regions, where the inclusion of rain precipitation in the high snow blanket also plays a role. The aforementioned truncated mean is approximately $4 \mathrm{MJ} \mathrm{ha}^{-1} \mathrm{~cm} \mathrm{~h}^{-1}$ lower for the given period than the standard arithmetic mean for the period, whilst at least the gross estimate of the total snow blanket leads in the average for the Czech Republic to another diminution of approximately 1 $\mathrm{MJ} \mathrm{ha}{ }^{-1} \mathrm{~cm} \mathrm{~h}^{-1}$. In the future it could be useful to consider the norm of erosive risk based on values of equal periodicity (e.g. 50 years), and not for the same period. The indicated $R$-Factor 
Table 4. Comparative values of $R$-Factor division for the Czech Republic, the USA and Bavaria.

\begin{tabular}{|c|c|c|c|c|c|c|c|c|}
\hline \multirow{2}{*}{ Factor values } & \multicolumn{8}{|c|}{ Division in given months } \\
\hline & IV & $\mathrm{V}$ & VI & VII & VIII & IX & $\mathrm{X}$ & XI \\
\hline$R$ division for the Czech Republic - meeting 1 of 2 requirements & 0.90 & 10.90 & 22.30 & 29.90 & 25.80 & 8.30 & 1.70 & 0.20 \\
\hline$R$ division for the Czech Republic - meeting both requirements & 0.50 & 8.90 & 22.80 & 33.50 & 27.40 & 6.30 & 0.50 & 0.10 \\
\hline$R$ division for Bavaria (18 omb. stations by Schwertmann, 1987) & 3.00 & 10.30 & 28.00 & 20.90 & 20.60 & 9.80 & 3.20 & 1.60 \\
\hline$R$ division for the USA & 0.40 & 9.10 & 33.20 & 28.40 & 20.80 & 7.70 & 1.00 & 0.00 \\
\hline
\end{tabular}

time distribution in the Czech Republic corresponds approximately to the distribution of the $R$-Factor on the isoerodent map for the state of Montana (USA), from 35 to $61 \mathrm{MJ} \mathrm{ha}^{-1} \mathrm{~cm} \mathrm{~h}^{-1}$. For this US state it was assessed (Kubatova et al., 2009) that the distribution and occurrence of erosive rains is very similar to the Czech Republic and in neighboring Bavaria - see Table 4.

On the basis of observed variations of erosion rainfall during each month it was confirmed that their highest occurrence is during the summer months (June-August).

\section{CONCLUSION}

From Fig. 4 we can conclude, provided that we do not assess mountainous areas with $R$-Factors of 60 to 120 where agricultural and, particularly, tilled land is very small and the influence of the snow blanket is greater, that the $R$-Factor for the majority of the land used for agricultural purposes in the Czech Republic, varies between 30 and 40, except in the area of rain shadow, where $R=15$ to 30 and low mountain areas with $R$-Factor 45 to 60 . With reference to the above-mentioned problems impairing the determination of the $R$-Factor, we may conclude that it does not appear as useful to regionalize the $R$-Factor for the Czech Republic (which, amongst others, corresponds to the exactness of the identification of isoerodents for the USA) and it may be better to accept - for the vast majority of the agricultural land in the Czech Republic - with the mean value of the $R$-Factor $=40$ $\mathrm{MJ} \mathrm{ha}{ }^{-1} \mathrm{~cm} \mathrm{~h}^{-1}$. When using this value it may be assumed that in the area of the rain shadow, somewhat higher resultant values of soil loss due to erosion will be assessed, with lower values in the low mountains.

If there is a need to determine soil risk and the implementation of soil protection in mountainous areas, usually forested or with permanent grassland and thus protected from erosion, it is possible to use higher values indicated on the map, considering longer-lasting snow blankets.

The comparison of long term monthly occurrence of erosion rainfall characterized by the divisions of $R$-Factor values for the Czech Republic and Montana in the USA indicates the occurrence of erosion rainfall in our conditions at the end of spring and start of summer (VII - VIII). Results indicated conformity of their division in the Czech Republic and selected regions of the USA. Therefore, it may be considered that the $R$-Factor entering the USLE complies with conditions in the Czech Republic.

The available $R$-Factor set, calculated from ombrographic data, is an original method for estimations of the yearly aggregate of the $R$-Factor from daily precipitation data. The method gives satisfying results compared with experimental data, although it surely would have been good to expand the scope of the set and solve open questions, as mentioned in the discussion. From the indicated results it can be concluded that, for the majority of the agricultural land in the Czech Republic, the value of $R$-Factor $=40$, double the of the value proposed thus far, could be recommended. This decision will surely manifest in higher demands for antierosion measures and will contribute significantly to the reduction of land loss due to erosion in the Czech Republic.

Acknowledgement. Supported by the Ministry of Agriculture of the Czech Republic, Project No. QH 72085.

\section{REFERENCES}

Angima, S.D., 2002. Soil erosion prediction using RUSLE for central Kenyan highland conditions. Journal of Sustainable Agriculture, 20, 3, 57-67.

Auerswald, K. et al., 2009. Rates of sheet and rill erosion in Germany - A meta-analysis. Geomorphology. 111, 3-4, 182-193.

Bonilla, C.A., Vidal, K.L., 2011. Rainfall erosivity in Central Chile. Journal of Hydrology, 410, 1-2, 126-133.

Braunovič, S. et al., 2009. Determination of rain erosive power factor $(\mathrm{R})$ for he region of Vranje aiming at the application of USLE method in our conditions. Advances in Geology, 41, 184-191.

Deumlich, D., Godicke, G., 1989. Studies on Threshold Levels of Erosion-Causing Precipitation in the Younger Moraine Region in the GDR. Archiv fur Acker und Pflanzenbau und Bodenkunde-Archives of Agronomy and Soil Science, 33, 11, 709-716.

Diodato, N., Bellocchi, G., 2010. MedREM, a rainfall erosivity model for the Mediterranean region. Journal of Hydrology, $387,1-2,119-127$.

Diodato, N. et al., 2012. Decadal modeling of rainfall-runoff erosivity in the Euro-Mediterranean region using extreme precipitation indices. Global and Planetary Changes, 86-87, 79-91.

Fujaltár, E., 2003. Assessment of soil erosion on arable land using Cs-137 measurements: a case study from Jaslovske Bohunice, Slovakia. Soil and Tillage research., 69, 1-2,139-152 .

Janeček, M., Květoň, V., Kubátová, E., Kobzová, D., 2012. Differentation and regionalization of Rainfall Erosivity Factor Values in the Czech Republic. Soil and Water Res., 7, 1, $1-9$.

Klik, A., Baumer, O.W., 1996. Soil and water conservation policies in Austria. Conference: International Conference on Soil and Water Conservation Policies and Programs. Successes and Failures, 371-379.

Kubátová, E., Janeček, M., Kobzová, D., 2009. Time variations of rainfall erosivity factor in the Czech Republic. Soil and Water Research, 4, 4, 131-141.

Pavelková, H., Dohnal, M., Vogel, T., 2012. Hillslope Runoff Generation - Comparing Different Modeling Approaches. Journal of Hydrology and Hydromechanics, 60, 2, 73-86.

Petrovšek, G., Mikoš, M., 2004. Estimating the R-Factor from daily rainfall data in the sub-Mediterranean climate of southwest Slovenia. Hydrological Sciences - Journal - des Sciences Hydrologiques, 49, 5, 869-877.

Rejman, J., Turski, R., Paluszek, J., 1998. Spatial and temporal variations in erodibility of less soil. Soil and Tillage Research, 46, 1-2, 61-68. 
Renard, K.G., Foster, G.R., Weesies, G.A., McCool, D.K., Yoder, D.C. 1997. Predicting Soil Erosion by Water: A Guid to Conservation Planning with the Revised Universal Soil Loss Equation (RUSLE). USDA Agriculture Handbook, No. 703.

Roksandic, M. et al., 2011. Bank erosion as a factor of soil loss and land use changes in the Koloubara River, Serbia. African Journal of Agriculture Research. 6, 32, 6604-6608.

Salles, C., Poesen, J., 1999. Performance of an Optical Spectro Pluviometer in measuring basis rain erosivity characteristics. Journal of Hydrology. 218, 3-4, 142-156.

Salles, C., Poesen, J., Sempere-Torres, D., 2002. Kinetic energy of rain and its functional relationship with intensity. Journal of Hydrology. 257, 1-4, 256-270.

Santosa, P.B. et al., 2010. Estimation of RUSLE $\mathrm{EI}_{30}$ based on 10 min interval rainfall data and GIS - based development of rainfall erosivity maps for Hitotsuse basin in Kyushu Japan. Department of Civil and Structural Engineering Kyushu University, Internation. Conference on Geoinformatics. Japan.

Schwertmann, U., Vogel, W., Kainz, M., 1987. Bodenerosion durch Wasser. E. Ulmer Gmbh, Stuttgart, 64 pp.
Strauss, P. et al., 1997. Evaluation of R - factors as exemplified by the Alsace region (France). Archives of Agronomy and Soil Science, 42, 2, 119-127.

Verstraeten, G. at al., 2006. Long-term (105 years) variability in rain erosivity as derived from 10-min rainfall depth data for Ukkel (Brussels, Belgium): Implications for assessing soil erosion rates. Journal of Geophysical Research, 111, D22.

Wischmeier, W.H., Smith, D.D., 1965. Predicting rainfall erosion losses from cropland east of the Rocky Mountains. Agricultural Handbook, No. 282, Washington.

Wischmeier, W.H., Smith, D.D., 1978. Predicting Rainfall Erosion Losses - A Guide to Conservation Planning. USDA Agriculture Handbook, No. 537, 55 pp.

Wordofa, G., 2011. Soil erosion modeling using GIS and RUSLE on the Eurajoki watersheds Finland. Bachelor's Thesis. Tampere University of Applied Science, Finland.

Received 22 November 2011

Accepted 6 December 2012 